\title{
Okul Müdürlerinin Toksik Liderlik Davranışları ile Öğretmenlerin Örgütsel Sessizliği arasındaki İlişsii*
}

\author{
Relationship between School Principals' Toxic Leadership \\ Behaviors and Teachers' Organizational Silence \\ Zülfü DEMIRTAŞ**, Özkan KÜÇÜK****
}

• Geliş Tarihi: 29.11.2018 • Kabul Tarihi: 04.03.2019 • Yayın Tarihi: 03.07.2019

\begin{abstract}
$\ddot{\mathbf{O} z}$
$\mathrm{Bu}$ çalışmada, lise ve ortaokul öğretmenlerinin okul müdürlerinin toksik liderlik davranışları ile kendi örgütsel sessizliklerine yönelik algılarının düzeyi ve müdürlerin toksik liderlik davranışlarının öğretmenlerin örgütsel sessizlikleri üzerindeki etkisi araştırılmıştır. Çalışma ilişkisel tarama modelindedir. Araştırma kapsamında Elazı̆̆ ili merkezinde küme örnekleme yoluyla belirlenen on lise ve sekiz ortaokulda görev yapan 411 öğretmene, Toksik Liderlik ve Örgütsel Sessizlik ölçekleri uygulanmıştır. Araştırma verilerinin analizinde ortalama ve standart sapmanın yanı sıra regresyon analizi uygulanmıştır. Öğretmenlerin beraber çalıştıkları okul müdürlerinin toksik liderlik davranışlarına yönelik algıları düşük düzeyde; kendi örgütsel sessizlik algıları orta düzeyde bulunmuştur. Okul müdürlerinin toksik liderlik davranışlarına yönelik öğretmenlerin algıları, örgütsel sessizliklerinin anlamlı bir yordayicisidir.
\end{abstract}

Anahtar Kelimeler: lider, toksik lider, örgütsel sessizlik

Atıf:

Demirtaş, Z., ve Küçük, Ö. (2019). Okul müdürlerinin toksik liderlik davranışları ile öğretmenlerin örgütsel sessizliği arasındaki ilişki. Pamukkale Üniversitesi Eğitim Fakültesi Dergisi,47, 41-58. doi: $10.9779 /$ pauefd.489747

\footnotetext{
* Bu çalışmanın ilk hali 13-15.05.2015 tarihlerinde düzenlenen ICEFIC 2015'te sözlü bildiri olarak sunulmuştur.

** Prof. Dr., Firat Üniversitesi, Eğitim Fakültesi, ORCID: 0000-0002-1072-5772, zdemirtas@ firat.edu.tr,

*** Doktora öğrencisi, Frrat Üniversitesi, Eğitim Bilimleri Enstitüsü, ORCID: 0000-0002-0340-6650, kucuko23@gmail.com,
} 


\begin{abstract}
The perception level of high school and secondary school teachers concerning toxic leadership behaviors of school administrators and their organizational silence behaviors and the effect of toxic leadership behaviors of school administrators on teachers' organizational silence was examined in this study. The study was carried out through the relational screening model. The Toxic Leadership and Organizational Silence scales were conducted on 411 teachers working in ten high schools and eight secondary schools in the province of Elazı $\breve{g}$ and which were selected through the cluster sampling method. A regression analysis along with the average and standard deviation values were used in analyzing the study data. Perception levels of teachers concerning the toxic leadership behaviors of their school administrators were observed to be at low level; perception levels concerning their own organizational silence behaviors were observed to be at moderate level. Teacher perceptions concerning toxic leadership behaviors of their school administrators are significant predictors of their organizational silence.
\end{abstract}

Keywords: leader, toxic leader, organizational silence

\title{
Cited:
}

Demirtaş, Z., \& Küçük, Ö. (2019). Relationship between school principals’ toxic leadership behaviors and teachers' organizational silence. Pamukkale Üniversitesi Eğitim Fakültesi Dergisi, 47, 4158. doi: 10.9779/pauefd.489747 


\section{Giriş}

Okulları amaçlarına ulaştırmada gereksinim duyulan en önemli öğenin, örgütsel kaynakların temin edilmesinde ve yetiştirilmesinde becerikli ve yeterli okul yöneticilerinin olduğu söylenebilir. İyi bir okul yöneticisinin okulun bütün çalışanlarına liderlik yapması beklenir. Liderlik, okulun hedeflerini gerçekleştirme doğrultusunda başkalarını etkileme gücüdür. $\mathrm{Bu}$ doğrultuda okul lideri tarafından, öğrenciye kişilik kazandırma ve hayatında işlevsel değeri olan bilgilere ulaşmasını sağlama yolunda eğitim hizmeti sunulur. Şişman (2002), okulların bu hizmetlerini ve amaçlarını yerine getirirken yoğun bir çaba göstermeleri gerektiğine vurgu yapmaktadir.

Liderlik konusunda yapılan araştırmaların çoğunda "iyi” ve "etkili" liderlik biçimlerini anlamaya (Uymaz, 2014, s. 39) ya da başarılı liderlik özelliklerinin neler olduğunu açıklamaya çalışılmıştır. Bu bağlamda, öğretimsel liderlik, kültürel liderlik, etik liderlik, süper liderlik, vizyoner liderlik ve tranformasyonel liderlik (Çelik, 2012) gibi liderlik yaklaşımları araştırmacıların ilgi odağı olmuş, bu liderlik tarzlarının örgütler açısından pozitif etkileri ortaya konmaya çalışılmıştır. Ancak, okul yöneticilerinin liderlik davranışları üzerinde uzlaşılmış genel bir özellikler listesi ortaya konmamıştır (Şişman, 2012).

Literatürde yer alan çok az sayıda araştırma işlevi olmayan, zarar verici liderliğin örgütlere etkilerini ve sonuçlarını ortaya koymayı amaçlamıştır. Bununla beraber son yıllarda, işlevsiz liderliğin daha detaylı olarak ele alınmaya başlandığı ifade edilebilir. Bu liderlik biçimlerinden birisi de toksik liderliktir. Olumsuz birçok liderlik özelliğinin bir arada değerlendirilmesi "toksik liderlik" olarak ifade edilmektedir. Latince "toksikus" olarak isimlendirilen toksik sözcügü, bir toksin veya zehir içeren bu yolla canlı organizma üzerinde hasara neden olan zararlı madde şeklinde ifade edilebilir. Buna bağlı olarak ortaya çıkan toksik olma durumuna ya da niteliğine "toksisite" denilmektedir (Kırbaç, 2013).

Toksik lider kavramını ilk kez Whicker (1996) kullanmış ve toksik liderliği uyumsuz, kötü niyetli ve huzursuz lider olarak ifade etmiştir (Çelebi, Güner ve Yıldız, 2015). Sonraki süreçte negatif durum ifade eden işlevsiz/yıkıcı liderlik çeşitlerinin (sahte dönüşümcü liderlik, kişisel karizmatik liderlik, stratejik zorbalık, yönetsel tiranlık) toksik liderlik ile ilişkisi araştırılmıştır (Uymaz, 2014). Goldman (2006), toksik liderliği "klinik olarak teşhis edilebilen, zihinsel rahatsızlığa sahip liderlik biçimi” olarak tanımlamıştır. Lipman-Blumen (2005), insanlar üzerinde korku ve endişe yaratan politikacıyı ya da şirketini iflasa götüren CEO'yu toksik lider şeklinde nitelemiştir. Wilson-Starks'a (2003) göre toksik lider, çalışanların grup davranışı ortaya koymasını işlevsiz hale getirmekte ve onları korkutarak kontrol altında tutmaktadır. Dyck'e (2001) göre toksik lider, çalışanların fiziksel ve ruhsal sağlığını bozmakta; Macklem'e (2005) göre, çalışanlar arasında duygusal gerilim ve devamsızlık oluşturmaktadır (Schmidt, 2014). Lubit (2004, s. 2-5) de toksik liderlerde bulunan özellikleri, narsist, agresif, sert- katı ve yetersiz lider şeklinde ifade etmiştir.

Toksik lider, çalışanların verimini düşürmekte, örgütün fayda-maliyet ilişkisine negatif etki etmekte, işe devam oranını düşürmekte ve grup düşüncesinin oluşmasına engel olmaktadır (Schmitd, 2008, s. 2). Diğer taraftan toksik lider, kendi toksik davranışlarını çalışanlara özümseten, örgüt başarısını kendisine, başarısızlığı çalışanlara mal etmeye çalışan ve değişimden olabildiğince kaçınan kişi olarak ifade edilmektedir (Eğinli ve Bitirim, 2008). 
Lipman-Blumen'a (2005, s. 2) göre toksik liderler, sergiledikleri davranışları ile farklı zehirleme (toksisite) düzeyinde bulunmaktadırlar. Bazı durumlarda örgüt ve çalışan açısından zehirli bir davranışta bulunurken, bir başka durumda ise olumlu bir tavır gösterebilmektedirler. Dolayısıyla toksik liderlerin çevrelerine yaydıkları zararlı sonuçların etki derecesi durumsal bir mahiyet göstermektedir. Schmitd'e (2008, s. 4-5) göre, toksik liderler, çalışanları göz ardı ederek, empati duygusundan uzak ve kendi kişisel ihtiyaçlarını ön planda tutma yönünde eğilim gösterirler. Wilson-Starks (2003), bu örgütlerde her şeye "evet" diyen kişilik özelliklerine sahip bireylerin ödüllendirildiğini; olaylara eleştirel bakabilen, farklı düşünen ve yaratıcı çalışanların önemli konumlardan uzak tutulmak suretiyle cezalandırıldığını ileri sürmektedir.

Toksik liderlerin bulunduğu örgütlerde, stres, düşük moral, mutsuzluk, gelecek kaygisı ve kötü iletişim vardır. Bu durum zamanla örgüt kültürü haline gelmektedir. Eğinli ve Bitirim'e (2008) göre, toksik lider, çalışanlar açısından kontrole dayalı yönetme stratejisi uygulayarak, onların yönetim konusunda kaygı yaşamalarına ve bazı risklerle karşılaşma endişesi taşımalarına yol açmaktadır. Dolayısıyla bu olumsuz davranışlar neticesinde çalışanlarda örgüte karş1 olumsuz bir tutumun ortaya çıkması ve örgüt işleyişinin bundan etkilenmesi beklenmektedir. Appelbaum ve Roy-Girard'a (2007, s. 18-20) göre, toksik liderlik özellikleri sergileyen yöneticilerin bulunduğu örgütlerde:

- Örgüt değerlerine bağl1lık konusunda yetersizlik,

- Problem çözme ve karar verme sürecinde korku,

- Zayıf- kötü bir iletişim,

- Kişisel çıkara dayalı bir iklim vardır.

Olumlu liderlik tarzları konusundaki çalışmalar (Boydak Özan, Türkoğlu ve Şener, 2010; Cemaloğlu, 2007; Çoğaltay, Karadağ ve Öztekin, 2014; Dunn, Dastoor ve Sims, 2012; Tahaoğlu ve Gedikoğlu, 2009; Uğurlu ve Üstüner, 2011; Yirci, Özdemir, Kartal ve Kocabaş,2014), liderlerin sergiledikleri pozitif davranışlarıyla örgütsel süreçlere etkilerini ortaya koymaya çalışmışlardır. Bununla beraber, bir lider, davranışlarıyla örgüt işleyişine katkı sağlamasa dahi toksik tavırlardan kaçınarak örgütsel çıktılar üzerinde pozitif sonuçlar elde edilmesine katk1 sunabilmektedir (Schmitd, 2014, s. 13).

Örgüt liderinden beklenen davranışların başında, çalışanların örgüte dair görüş ve düşüncelerini serbestçe ifade etmeleri için bir ortam sunmalarıdır. Bu durum, artan rekabet koşullarında kalite standartlarını yükseltmek ve sürekli değişen ve gelişen toplumun beklentilerine cevap verme amacı taşıyan modern çağın örgütlerinden beklenen bir görevdir. $\mathrm{Bu}$ doğrultuda örgütler, çalışanlarından bilgi paylaşımını arttırmaları (Nartgün ve Kartal, 2013), sorumluluk bilinciyle hareket etmeleri, fikirlerini beyan etmekten çekinmemeleri ve kendilerine güvenmeleri hususunda daha çok titiz davranmalarını beklemektedirler (Taşkıran, 2010). Kılıç, Keklik ve Yıldız'a (2014) göre, örgütsel sessizlik sorunu birçok örgütte görülmesine rağmen örgütsel sessizlik ile liderlik tarzları arasındaki ilişki konusunda çok az akademik çalışma yapılmıştır. Kılınç'a (2012) göre bu durum sessizlik davranışını araştırmanın zorluğundan kaynaklanmaktadır.

Örgütsel sessizlik, çalışanların, görev alanı ile ilgili görüş ve düşüncelerini ifade etmekten kaçınmalarıdır (Milliken, Morrison ve Hewlin, 2003). Henriksen ve Dayton (2006) 
sessizliği, ciddi örgütsel problemlere karşı basit tepkiler verme olarak tanımlamıştır. Başka bir açıdan örgütü daha iyi bir duruma yükseltebilecek kabiliyetlerini bilişsel, duyuşsal ve davranışsal olarak gizlemeleridir (Pinder ve Harlos, 2001, s. 334). Bu sessizlik; amaçlı, bilinçli ve kasıtlı bir davranış olup örgütsel değişim ve gelişimin önünde ciddi bir sorun oluşturma olasılığını beraberinde getirmektedir. Taşkıran'a (2010) göre, sessizliğin temelinde diğer üyeler tarafından dışlanma ve işini kaybetme endişesi yatmaktadır. Bildik (2009) bunları, yöneticilere güvenilmemesi, konuşmaların riskler doğuracağı endişesi, dışlanma korkusu, geçmiş tecrübeler ve ilişkilere zarar verme korkusu olarak ifade etmektedir.

Örgüt açısından, çalışanların yöneticilere karşı kendilerini güvende hissetmemelerinin onlar açısından önemli bir sorun teşkil ettiği kabul edilmektedir (Gül ve Özcan, 2011). Çalışanların örgütsel sessizliğe bürünmelerinin değişik nedenlerden kaynaklanabileceği ifade edilmektedir. Aşağıda örgüt çalışanlarının sessiz kalmalarına yol açan faktörlere ilişkin bir model yer almaktadır.

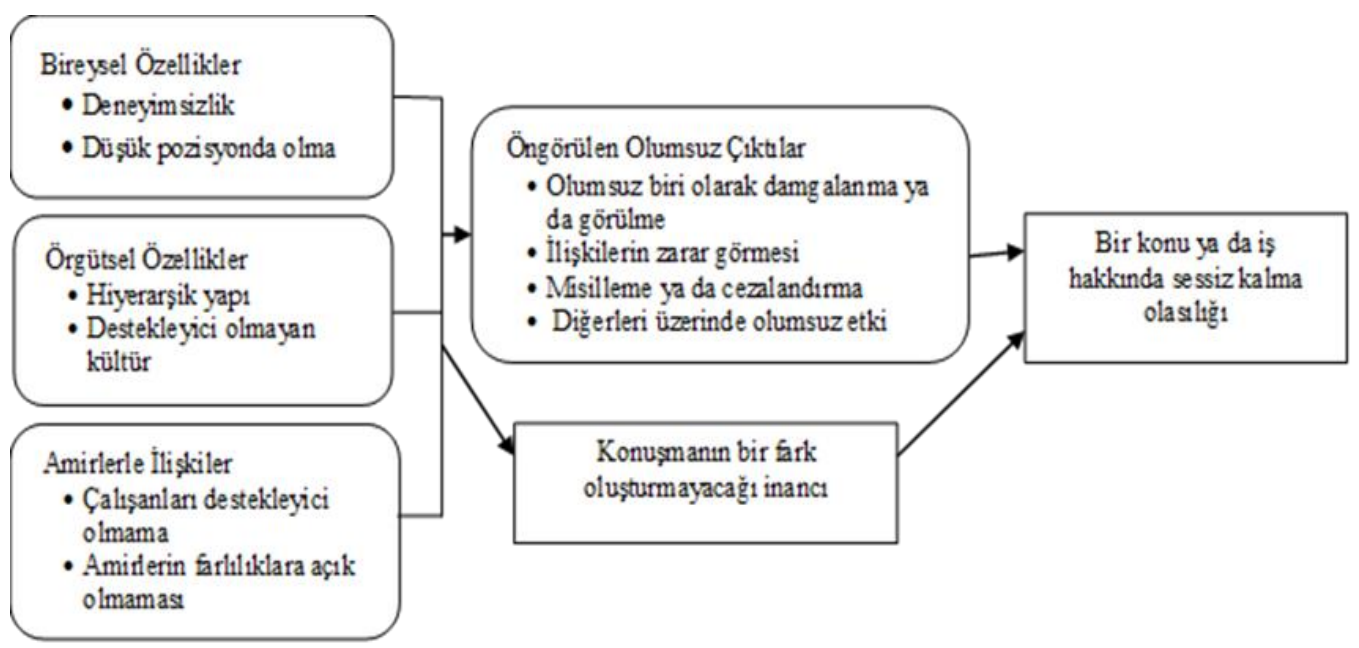

Şekil 1: Çalışanların sessiz kalmalarına yol açan faktörlere ilişkin bir model

Kaynak: Frances J. Milliken, Elizabeth W. Morrison and Patrica F. Hewlin. (2003). An exploratory study of employee silence: Issues that employees don't communicate upward and why. Journal of management studies, 40(6), 1453-1476, s.1467.

Bireysel faktörler, örgütsel faktörler ve üst ile ilişkiler, örgüt çalışanlarının sessiz kalmalarına yol açmaktadır. Bu faktörlere bağlı olarak ortaya çıkan sessizlik davranışı sonucunda çalışanın olumsuz algılanması (etiketlenme), kişilerarası ilişkilerin zarar görmesi, işten çıkarılma gibi cezalara neden olma durumları ortaya çıkmaktadır. Diğer taraftan, çalışanların konuşmanın herhangi bir şeyi değiştirmediğine ve örgüt açısından bir anlam ifade etmediğine olan inançları onları sessizliğe yöneltmektedir.

Örgütsel sessizlik davranışı bütün örgütlerde karşılaşılabilen bir durumdur. Özellikle karar süreçleri, yönetimin yetersizliği, kaynakların paylaşılması, düşük örgütsel performans konuları tartışılmaz hususlar olarak görülmektedir (Kahveci ve Demirtaş, 2013, s. 54). Çalışanlar, sözü edilen konularda görüş belirtmenin bir şey değiş̧irmeyeceğine inanarak, olumsuz yanıtlar alabilecekleri endişesi taşıdıklarında sessiz kalmayı tercih etmektedirler (McGowan, 2003). Crockett (2013), çalışanların, fikir ve düşüncelerini beyan ettiklerinde 
şikâyet eden ya da sorun yaratan kişi durumuna düşebileceklerini varsaydıkları için sessizlik davranışı sergilediklerini ifade etmektedir.

Örgütsel sessizliğin ortaya çıkmasında örgüt kültürü önemli bir rol oynamaktadır. Fujio (2004) tarafından yapılan bir araştırmada, çalışanların sessizlik davranışı ile kültür arasında yakın bir ilişki bulunmuştur. Çalışmada Japon çalışanlar ile Amerikalı çalışanların sessizlik davranışları arasında farklılıklar tespit edilmiştir. Japon kültüründe kişilerarası ilişkiler Amerikan kültürüne göre daha samimi ve sıcak bir nitelik gösterdiğinden, Japon kültürü açısından sessizlik davranışı, olumlu havanın bozulmaması adına pozitif bir durum olarak algılanırken, Amerikan kültürü açısından bu durum olumsuz ve değersiz kabul edilmektedir. Literatürde yöneticilerin toksik liderlik davranışları ile çalışanların örgütsel sessizlik davranışları arasındaki ilişkiyi inceleyen bir araştırmaya ulaşılamamıştır. Eğitim örgütlerinde müdürlerin toksik liderlik davranışları ile öğretmenlerin örgütsel sessizlikleri arasında bir ilişkinin olup olmadığı önem taşımaktadır. Müdürlerin toksik davranışlarının öğretmenlerin örgütsel sessizlik düzeyleri üzerinde anlamlı bir etkisi olduğunu düşünüyoruz. Bu bağlamda, okul müdürlerinin sahip olduğu toksik liderlik davranışlarının öğretmenlerin örgütsel sessizliğini artırıp artırmadığı önem taşımaktadır. Bu araştırmanın temel amacı öğretmenlerin kendi müdürlerinin toksik liderlik davranışlarına yönelik algıları ile kendi örgütsel sessizlik davranışları arasındaki ilişkinin incelenmesidir. Bu bağlamda aşağıdaki alt amaçlara ulaşılması hedeflenmektedir:

1. Öğretmenlerin kendi müdürlerinin toksik liderlik davranışları ile ilgili algıları hangi düzeydedir?

2. Öğretmenlerin kendi örgütsel sessizlikleri ile ilgili algıları hangi düzeydedir?

3. Müdürlerin toksik liderlik davranışları ile ilgili öğretmen algıları, onların örgütsel sessizliklerinin anlamlı bir yordayıcısı mıdır?

\section{Yöntem}

$\mathrm{Bu}$ araştırma, iki ve daha çok sayıdaki değişken arasında birlikte değişim varlığını ya da derecesini belirlemeyi amaçlayan ilişkisel tarama modelindedir. Bu modelde, aralarında ilişki aranacak değişkenlerin ilişkisel bir çözümlemeye imkân verecek şekilde sembolleştirilmesi gerekmektedir (Karasar, 2012, s. 81).

\section{Evren ve Örneklem}

Araştırmanın evreni, Elazığ'da resmi lise ve ortaokullarda görev yapan 2603 lise ve 2422 ortaokul öğretmeninden oluşmaktadır. Örneklem ise Elazığ ili merkezinde ve küme örnekleme yoluyla belirlenen beş Anadolu Lisesi, dört Mesleki ve Teknik Anadolu Lisesi ve bir Sosyal Bilimler Lisesi olmak üzere 10 lise ile dört eğitim bölgesinin her birinden seçilen ikişer okul olmak üzere toplam sekiz ortaokuldan oluşmaktadır. Bu kapsamda araştırmaya 196 (112 erkek, 84 kadın) lise öğretmeni ve 215 (141 erkek, 74 kadın) ortaokul öğretmeni olmak üzere toplam 411 öğretmen katılmıştır. Araştırmada örneklemin güven aralığı \% 95, buna bağlı olarak hata oranı (z) da 1.96 olarak belirlenmiştir. 


\section{Veri Toplama Araçları}

Araştırmada veri toplama aracı olarak "Toksik Liderlik Ölçeği” ve "Örgütsel Sessizlik” Ölçeği kullanılmıştır.

\section{Toksik Liderlik Ölçeği}

Toksik Liderlik Ölçeği, Schmidt (2008) tarafindan 30 madde olarak geliştirilmiş ve Dobbs (2014) tarafından 15 madde içerecek şekilde yeniden düzenlemiştir.

Mevcut araştırma kapsamında, 15 maddeli ölçek, iki araştırmacı tarafından önce İngilizceden Türkçeye, sonra Türkçeden İngilizceye çevrilmiştir. İki çeviri karşılaştırılmış ve ortak bir Türkçe versiyonu elde edilmiştir. Ölçek, beş faktörden oluşmaktadır. Bu faktörler ve içerdikleri maddeler sırasıyla şöyledir: kendi reklamını yapma (1., 2., 3. maddeler), istismar edici denetmenlik (4., 5., 6. maddeler), öngörülemezlik (7., 8., 9. maddeler) narsizm (10., 11., 12. maddeler) ve otoriter liderlik (13., 14., 15. maddeler). Dobbs (2014), ölçeğin her bir boyutu için Cronbach Alpha's güvenirlik katsayısını yüksek düzeyde elde etmiştir: kendi reklamını yapma (.91), istismar edici denetmenlik (.93), öngörülemezlik (.92), narsizm (.88), otoriter liderlik (.89) ve ölçeğin tümünü (.90). Bu araştırma kapsamında yapılan Cronbach Alpha's güvenirlik katsayıları sırasıyla; kendi reklamını yapma (.92), istismar edici denetmenlik (.88), öngörülemezlik (.64), narsizm (.83), otoriter liderlik (.48) ve ölçeğin tümü (.89) şeklinde bulunmuştur. Bu sonuçlara göre ölçeğin güvenilir olduğu ifade edilebilir. Ölçeğe Doğrulayıc1 Faktör Analizi (DFA) uygulanmış, uyum iyiliği değerleri kabul edilebilir düzeyde bulunmuştur $\left(\mathrm{x}^{2} / \mathrm{df}=3.807 ; \mathrm{GFI}=.911 ; \mathrm{AGFI}=.866 ; \mathrm{CFI}=.945 ; \mathrm{NFI}=.927 ; \mathrm{TLI}=.928 ; \mathrm{RMSEA}=.083\right.$ ve SRMR=.041). Bu değerler ölçeğin orijinal halindeki beşli faktör yapısının (kendi reklamını yapma, istismar edici denetmenlik, öngörülemezlik, narsizm ve otoriter liderlik) geçerliliğini koruduğunun kanıtı olarak kabul edilmiştir.

\section{Örgütsel Sessizlik Ölçeği}

Kahveci ve Demirtaş (2013) tarafindan geliştirilen Örgütsel Sessizlik Ölçeği 18 madde ve beş faktörden oluşmaktadır. Bu faktörler sırasıyla "okul ortamı", "duygu”, "sessizliğin kaynağı", "yönetici" ve "izolasyon" şeklindedir. Okul ortamı boyutunda dört madde $(1,2,3,4)$, duygu boyutunda üç madde $(5,6,7)$, sessizliğin kaynağı boyutunda beş madde $(8,9,10,11,12)$, yönetici boyutunda üç madde $(13,14,15)$ ve izolasyon boyutunda üç madde $(16,17,18)$ bulunmaktadır. Kahveci ve Demirtaş (2013), ölçeğin her bir boyutu için Cronbach Alpha's güvenirlik katsayısını okul ortamı boyutunda (.74), duygu boyutunda (.81), sessizliğin kaynağı boyutunda (.80), yönetici boyutunda (.79), izolasyon boyutunda (.83) ve ölçeğin tümü için (.89) olarak hesaplamışır. Bu araştırma kapsamında yapılan Cronbach Alpha's güvenirlik katsayısı hesaplamasında ölçeğin okul ortamı (.49), duygu (.71), sessizliğin kaynağı (.67), yönetici (.81), izolasyon (.78) ve ölçeğin tümü (.81) olarak hesaplanmıştır. Bu sonuçlara göre ölçeğin güvenilir olduğu ifade edilebilir. Ölçeğe DFA uygulanmıştır. DFA sonuçları ölçeğin uyum iyiliği değerlerinin kabul edilebilir düzeyde olduğunu göstermektedir $\left(\mathrm{x}^{2} / \mathrm{df}=3.209 ; \mathrm{GFI}=.898\right.$; AGFI=.860; CFI=.891; NFI=.850; TLI=.866; RMSEA=.073 ve SRMR=.067). Bu değerler doğrultusunda ölçeğin orijinal halindeki beşli faktör yapısının (okul ortamı, duygu, sessizliğin kaynağı, yönetici ve izolasyon) korunduğu söylenebilir. 


\section{Verilerin Analizi}

Öğretmen görüşlerine göre okul müdürlerinin toksik liderlik davranışları ile öğretmenlerin örgütsel sessizlik davranışları arasındaki ilişkiye dair nicel sorulardan elde edilen veriler bir paket program kullanılarak analiz edilmiştir. Veriler değerlendirilirken tanımlayıcı istatistiksel metotlar (ortalama ve standart sapma) kullanılmıştır.

Araştırmanın bağımlı ve bağımsız değişkenleri arasındaki yordama düzeyi regresyon analizi ile test edilmiştir. Regresyon analizi yapılırken standart "Enter" metodu uygulanmıştır. Ayrıca yordayıcı değişkenler arasındaki çoklu korelasyon derecesini belirlemek için tolerans değerlerine bakılmış, sorun teşkil edecek bir ilişkinin olmadığı görülmüştür.

Ölçekler beşli likert tipi olup maddeler "(1) Kesinlikle katılmıyorum", "(2) Katılmıorum" "(3) Orta düzeyde katılıyorum", "(4) Katılıyorum", "(5) Tamamen katılıyorum" şeklinde puanlanmıştır. Alınan görüşlerin yorumlanması için elde edilecek sonuçların aralıkları"1,00-1,80 Kesinlikle katılmıyorum", "1.81-2.60 Katılmıyorum", "2.61-3.40 Orta düzeyde katılıyorum”, "3.41-4.20 Kat1lyorum” ve "4.21-5.00 Kesinlikle kat1lıyorum” şeklinde belirlenmiștir.

\section{Bulgular}

Öğretmenlerin, okul müdürlerinin toksik liderlik davranışları ve kendi örgütsel sessizlik davranışlarına ilişkin algılarına dair ortalama puanlarını belirlemek amacıyla yapılan analiz sonuçları Tablo 1'de verilmiştir.

Tablo 1. Öğretmenlerin Müdürlerinin Toksik Liderlik Davranışları ve Kendi Örgütsel Sessizlik Davranışları ile ilgili Algılarının Ortalama ve Standart Sapmaları

\begin{tabular}{lllll}
\hline Ölçek & Boyut & $\mathrm{N}$ & $\overline{\mathrm{x}}$ & $\mathrm{SS}$ \\
\hline \multirow{4}{*}{ Toksik Liderlik } & Kendi Reklamını Yapma & 411 & 1.91 & .906 \\
& İstismar Edici Denetmenlik & 411 & 1.79 & .846 \\
& Öngörülemezlik & 411 & 2.05 & .785 \\
& Narsizm & 411 & 1.74 & .759 \\
& Otoriter Liderlik & 411 & 2.25 & .738 \\
& Toksik Liderlik & 411 & 1.93 & .676 \\
\hline \multirow{4}{*}{ Örgütsel Sessizlik } & Okul Ortamı & 411 & 2.99 & .702 \\
& Duygu & 411 & 3.41 & .900 \\
& Sessizliğin Kaynağı & 411 & 2.88 & .744 \\
& Yönetici & 411 & 3.28 & 1.051 \\
& İzolasyon & 411 & 3.06 & .939 \\
& Örgütsel Sessizlik & 411 & 3.13 & .667 \\
\hline
\end{tabular}

Tablo 1'e göre öğretmenlerin kendi okul müdürlerinin toksik liderlik davranışlarına yönelik algıları, istismar edici denetmenlik $(\overline{\mathrm{X}}=1.88)$ ve narsizm $(\overline{\mathrm{X}}=1.74)$ boyutlarında "kesinlikle katılmıyorum" düzeyinde; kendi reklamını yapma, öngörülemezlik ve otoriter liderlik boyutlarında ise "katılmıyorum" düzeyindedir. Ayrıca beş boyutun ortalaması da katılmıyorum düzeyinde gerçekleşmiştir. Öğretmenlerin kendi örgütsel sessizliklerine yönelik algıları bütün boyutlarda orta düzeyde geçekleşmiştir. Duygu boyutundaki ortalamalar bu aralığın üst sınırındadır. 
Tablo 2. Toksik Liderlik Davranışlarının Örgütsel Sessizliğin Beş Boyutunu Yordamasına ilişkin Regresyon Analizi Sonuçları

\begin{tabular}{|c|c|c|c|c|c|c|c|c|}
\hline $\begin{array}{l}\text { Bağımlı } \\
\text { Değişken }\end{array}$ & Bağımsız Değişken & $\beta$ & $\mathrm{t}$ & $\mathrm{p}$ & $\mathrm{F}$ & $\begin{array}{l}\text { Model } \\
\text { (p) }\end{array}$ & $\mathrm{R}^{2}$ & $\begin{array}{c}\text { Düzeltilmiş } \\
\mathrm{R}^{2}\end{array}$ \\
\hline \multirow{6}{*}{$\begin{array}{l}\text { Okul } \\
\text { Ortamı }\end{array}$} & Sabit & & 22.376 & .000 & \multirow{6}{*}{7.026} & \multirow{6}{*}{.000} & \multirow{6}{*}{.080} & \multirow{6}{*}{.068} \\
\hline & Kendi Reklamını Yapma & .278 & 3.460 & .001 & & & & \\
\hline & İstismar Edici Denetmenlik & -.124 & -1.321 & .187 & & & & \\
\hline & Öngörülemezlik & .191 & 2.798 & .005 & & & & \\
\hline & Narsizm & -.035 & -.412 & .681 & & & & \\
\hline & Otoriter Liderlik & -.059 & -1.001 & .317 & & & & \\
\hline \multirow{6}{*}{ Duygu } & Sabit & & 19.339 & .000 & \multirow{6}{*}{5.269} & \multirow{6}{*}{.000} & \multirow{6}{*}{.061} & \multirow{6}{*}{.049} \\
\hline & Kendi Reklamını Yapma & .157 & 1.938 & .053 & & & & \\
\hline & İstismar Edici Denetmenlik & -.087 &,- 916 & .360 & & & & \\
\hline & Öngörülemezlik & .262 & 3.797 & .000 & & & & \\
\hline & Narsizm & -.118 & -1.385 & .167 & & & & \\
\hline & Otoriter Liderlik & -.002 & -.041 & .967 & & & & \\
\hline \multirow{6}{*}{$\begin{array}{l}\text { Sessizliğin } \\
\text { Kaynağ1 }\end{array}$} & Sabit & & 18.195 & .000 & \multirow{6}{*}{9.899} & \multirow{6}{*}{.000} & \multirow{6}{*}{.109} & \multirow{6}{*}{.098} \\
\hline & Kendi Reklamını Yapma & .119 & 1.536 & .133 & & & & \\
\hline & İstismar Edici Denetmenlik & .065 & .701 & .484 & & & & \\
\hline & Öngörülemezlik & .176 & 2.625 & .009 & & & & \\
\hline & Narsizm & -.004 & -.047 & .962 & & & & \\
\hline & Otoriter Liderlik & .024 & .412 & .680 & & & & \\
\hline \multirow{6}{*}{ Yönetici } & Sabit & & 15.150 & .000 & \multirow{6}{*}{5.043} & \multirow{6}{*}{.000} & \multirow{6}{*}{.059} & \multirow{6}{*}{.047} \\
\hline & Kendi Reklamını Yapma & .220 & 2.706 & .007 & & & & \\
\hline & İstismar Edici Denetmenlik & -.119 & -1.251 & .212 & & & & \\
\hline & Öngörülemezlik & .198 & 2.873 & .004 & & & & \\
\hline & Narsizm & -.092 & -1.072 & .284 & & & & \\
\hline & Otoriter Liderlik & .022 & .363 & .717 & & & & \\
\hline \multirow{6}{*}{ İzolasyon } & Sabit & & 15.393 & .000 & \multirow{6}{*}{7.540} & \multirow{6}{*}{.000} & \multirow{6}{*}{.085} & \multirow{6}{*}{.074} \\
\hline & Kendi Reklamını Yapma & .291 & 3.642 & .000 & & & & \\
\hline & İstismar Edici Denetmenlik & -.051 & -.542 & .588 & & & & \\
\hline & Öngörülemezlik & .121 & 1.772 & .077 & & & & \\
\hline & Narsizm & -.094 & -1.115 & .265 & & & & \\
\hline & Otoriter Liderlik & .038 & .644 & .520 & & & & \\
\hline
\end{tabular}

Tablo 2'ye göre, toksik liderliğin beş boyutu okul ortamı boyutunda öğretmenlerin örgütsel sessizliğini anlamlı düzeyde yordamaktadır $(\mathrm{F}=7.026 ; \mathrm{p}=.000)$. Okul ortamı düzeyinin belirleyicisi olarak kendi reklamını yapma, istismar edici denetmenlik, öngörülemezlik, narsizm ve otoriter liderlik değişkenlerinin ilişkisi (açılayıcılık gücü) anlamlı olmasına rağmen zayıftır $\left(\mathrm{R}^{2}=.080\right)$. Söz konusu beş değişken, birlikte, sessizliğin okul ortamı düzeyindeki değişimin \%8'ini açıklamaktadır. Ancak diğer değişkenler dikkate alındığında, bu beş değişkenin okul ortamı boyutunu açıklama düzeyi biraz daha düşerek \%7 düzeyine inmektedir (düzeltilmiş $\mathrm{R}^{2}=.068$ ). Yordayıcı değişkenlerin okul ortamı boyutu üzerindeki etki düzeyleri sırasıyla şöyledir: kendi reklamını yapma ( $\beta=.278$ ), istismar edici denetmenlik ( $\beta=$ -.124), öngörülemezlik ( $\beta=.191)$, narsizm $(\beta=-.035)$ ve otoriter liderlik $(\beta=-.059)$.

Toksik liderlik boyutlarının örgütsel sessizliğin duygu boyutu üzerindeki etkisi anlamlıdır $(\mathrm{F}=5.269 ; \mathrm{p}=.000)$. Duygu düzeyini belirlemede beş boyut zayıf bir etkiye sahiptir 
$\left(\mathrm{R}^{2}=.061\right)$. Toksik liderliğin beş boyutu birlikte, sessizliğin duygu boyutu düzeyindeki değişiminin \%6'sını açıklamaktadır. Ancak diğer değişkenler dikkate alındığında bu beş değişkenin duygu boyutunu açıklama gücü \%4.5 düzeyine inmektedir (düzeltilmiş $\mathrm{R}^{2}=.049$ ). Tek başlarına yordayıcı değişkenlerden sadece öngörülemezlik $(\mathrm{p}<.05)$ değişkeninin duygu boyutu üzerinde anlamlı yordayıcı olduğu, diğer değişkenlerin anlamlı yordayıcı olmadığ görülmektedir. Standartlaştırılmış regresyon katsayılarına göre, yordayıcı değişkenlerin duygu boyutu üzerindeki etki düzeyi sırasıyla şöyledir: kendi reklamını yapma $(\beta=.157)$, istismar edici denetmenlik $(\beta=-.087)$ öngörülemezlik $(\beta=.262)$, narsizm $(\beta=-.118)$ ve otoriter liderlik $(\beta=-.002)$.

Toksik liderlik boyutlarının, sessizliğin kaynağı boyutu üzerindeki etkisi anlamlıdır ( $\mathrm{F}=$ 9.899; $\mathrm{p}=.000$ ). Sessizliğin kaynağı düzeyinin belirleyicisi olarak beş boyut ile ilişkisinin zayıf olduğu görülmüştür $\left(\mathrm{R}^{2}=.109\right)$. Bu beş boyut, birlikte, sessizliğin kaynağı düzeyindeki değişimin \%11'ini açıklamaktadır. Ancak diğer değişkenler dikkate alındığında, bu beş değiş̧kenin sessizliğin kaynağı boyutunu açıklama gücü \%10 düzeyine inmektedir (düzeltilmiş $\mathrm{R}^{2}=.098$ ). Regresyon katsayılarının anlamlılık testlerine bakıldığında, tek başlarına yordayıcı değişkenlerden öngörülemezlik $(\mathrm{p}<.05)$ boyutunun sessizliğin kaynağı boyutu üzerinde anlamlı yordayıcı olduğu, diğer boyutların anlamlı yordayıcı olmadığı görülmektedir. Standartlaştırılmış regresyon katsayılarına göre, yordayıcı değişkenlerin sessizliğin kaynağı boyutu üzerindeki etki düzeyi sırasıyla şöyledir: kendi reklamını yapma $(\beta=.119)$, istismar edici denetmenlik ( $\beta$ $=.065)$ öngörülemezlik $(\beta=.176)$, narsizm $(\beta=-.004)$ ve otoriter liderlik $(\beta=.024)$.

Toksik liderlik boyutlarının, örgütsel sessizliğin yönetici boyutu üzerindeki etkisi anlamlıdır $(\mathrm{F}=5.043 ; \mathrm{p}=.000)$ ve bu etki düşük düzeydedir $\left(\mathrm{R}^{2}=.059\right)$. Toksik liderliğin beş boyutu, birlikte, sessizliğin yönetici düzeyindeki değişimin \%6'sını açılamaktadır. Ancak diğer değişkenler dikkate alındığında bu beş değişkenin yönetici boyutunu açıklama düzeyi biraz daha düşerek $\% 5$ düzeyine inmektedir (düzeltilmiş $\mathrm{R}^{2}=.047$ ). Regresyon katsayılarının anlamlılık testlerine bakıldığında, tek başlarına yordayıcı değişkenlerden kendi reklamını yapma ve öngörülemezlik $(\mathrm{p}<.05)$ boyutlarının yönetici boyutu üzerinde anlamlı yordayıcı olduğu, diğer boyutların anlamlı yordayıcı olmadığı görülmektedir. Standartlaştırılmış regresyon katsayılarına göre, yordayıcı değişkenlerin yönetici boyutu üzerindeki etki düzeyi sırasıyla şöyledir: kendi reklamını yapma $(\beta=.220)$, istismar edici denetmenlik $(\beta=-.119)$ öngörülemezlik $(\beta=.198)$, $\operatorname{narsizm}(\beta=-.092)$ ve otoriter liderlik $(\beta=.022)$.

Toksik liderlik boyutlarının, örgütsel sessizliğin izolasyon boyutu üzerindeki etkisi anlamlı $(\mathrm{F}=7.540 ; \mathrm{p}=.000)$ olup düşük düzeydedir $\left(\mathrm{R}^{2}=.085\right)$. Toksik liderliğin beş boyutu, birlikte, sessizliğin izolasyon düzeyindeki değişimin \%8'ini açıklamaktadır. Ancak diğer değişkenler dikkate alındığında bu beş değişkenin izolasyon boyutunu açıklama gücü \%7 düzeyine inmektedir (düzeltilmiş $\mathrm{R}^{2}=.074$ ). Regresyon katsayılarının anlamlılık testlerine bakıldığında, tek başlarına yordayıcı değişkenlerden kendi reklamını yapma boyutunun izolasyon boyutu üzerinde anlamlı yordayıcı olduğu, diğer boyutların anlamlı yordayıc1 olmadığı görülmektedir. Standartlaştırılmış regresyon katsayılarına göre, yordayıcı değişkenlerin izolasyon üzerindeki etki düzeyi sırasıyla şöyledir: kendi reklamını yapma ( $\beta=$ $.291)$, istismar edici denetmenlik ( $\beta=-.051)$ öngörülemezlik $(\beta=.121)$, narsizm $(\beta=-.094)$ ve otoriter liderlik $(\beta=.038)$. 
Regresyon analizi sonuçlarına göre, örgütsel sessizliği yordayan regresyon denklemi şu şekildedir:

Örgütsel Sessizlik $=(.205 \times$ kendi reklamını yapma $)+(-.068 \times$ istismar edici denetmenlik $)+(.210 \times$ öngörülemezlik $)+(-.084 \times$ narsizm $)+(.009 \times$ otoriter liderlik $)$.

\section{Sonuç ve Tartışma}

Ortaokul ve liselerde görev yapan öğretmenler, birlikte görev yaptıkları okul müdürlerinin istismar edici denetmenlik ve narsizm boyutlarında toksik liderlik davranışı gösterdiklerine kesinlikle katılmamaktadırlar. Diğer bir ifade ile öğretmenler, okul müdürlerinin bu iki boyutta toksik liderlik davranışlarını sergilemedikleri yönünde algılara sahiptirler. Okul müdürleri, görevlerini yerine getirirken müdürlük makamını bir istismar aracı olarak kullanmaktan kaçınmaktadırlar. Öğretmenlerin bu yöndeki algıları, okul müdürlerinin görevin gerektirdiği davranışlar sergilediklerinin ve kendi bireysel isteklerine göre hareket etmediklerinin bir göstergesi olarak görülmelidir. $\mathrm{Bu}$ yönü ile okul müdürlerinin dayanışmacı davranışlar sergiledikleri söylenebilir. Kendi reklamını yapma, öngörülemezlik ve otoriter liderlik boyutlarında okul müdürlerinin sergiledikleri davranışlar "katılmıyorum" düzeyinde gerçekleşmiştir. Ancak bu ortalamalar "kesinlikle katılmıyorum" düzeyine çok yakındır. Bütün olarak değerlendirildiğinde, ortaokul ve liselerde görev yapan öğretmenler, okul müdürlerinin toksik liderlik davranışları sergilediklerine yönelik algılara sahip değildirler.

Araştırma bulguları daha önce yapılmış araştırma bulguları ile benzerlik göstermektedir. Dobbs (2014) tarafından yapılan çalışmada çalışanların, liderleri hakkında düşük düzeyde toksik liderlik algılarına sahip oldukları görülmüştür. Her iki çalışmada ulaşılan bulgular, müdürlerin, astlarıyla alay etme, aşırı öfkelenme ve ağır iş yükleme gibi olumsuz liderlik davranışlarından kaçındıklarını göstermektedir. Dolayısıyla, katılımcıların düşük düzeyde toksik liderlik algılarına sahip olmaları öğretmenlerin; okul yöneticilerinin uygulamaları konusunda kaygı taşımadıklarını göstermektedir. Diğer yandan, Schmidt (2008) tarafından yapılan araştırmada ulaşılan bulgular, bu çalışmanın bulguları ile çelişmekte ve çalışanların kendi yöneticilerinin toksik liderlik davranışlarına yönelik algılarının yüksek düzeyde olduğunu göstermektedir.

Katılımcıların kendi örgütsel sessizliklerine yönelik algıları bütün boyutlarda orta düzeydedir. Ancak duygu boyutunda algılar diğer boyutlardan daha yüksektir. Bu bulgular, literatürde yer alan araştırma sonuçları ile benzerlik göstermektedir. Daşçı (2014), Demirtaş (2018), Demirtaş, Özdemir ve Küçük (2016), Karaman (2015), Kılıç, Tunç, Saraçlı ve Kılıç (2013) tarafından yapılan çalışmalarda, katılımcıların orta düzeyde sessizlik algısına sahip oldukları görülmüş̧ür. Bu araştırmanın bulgularından farklı sonuçlar ortaya koyan çalışmalar da bulunmaktadır. Bu kapsamda, Şimşek ve Aktaş (2014) tarafından yapılan çalışmada, çalışanların orta düzeyin biraz üstünde, Demirtaş ve Nacar (2018) tarafından yapılan çalışmada orta düzeyde, Kahya (2015) tarafından yapılan çalışmada ise orta düzeyin biraz altında sessizlik algısına sahip oldukları görülmüştür. Sessizlik davranışı, kültür farklılığına sahip toplumlarda ve dolayısıyla örgütlerde farklı yorumlanabilmektedir. Öğretmenlerin görev yaptıkları okullarda yönetici ve diğer meslektaşlarıyla ilişkilerinde duygu boyutunda diğer boyutlara göre daha fazla sessiz kalma davranışlarının iyi analiz edilmesine gereksinim vardır. Duygu boyutu, öğretmenlerin güç durumlarda konuşmaktan çok susmayı tercih etmelerini; belirli konular 
hakkında (yöneticinin statüsünü tartışma, meslektaşlarının eksik yönlerini tartışma vb.) konuşmaktan kaçınmalarını ölçmektedir.

Örgütsel sessizlik ölçeğine verilen yanıtlar, öğretmenlerin orta düzeyde örgütsel sessizlik davranışı sergilediklerini göstermektedir. Bu bulgular Türk toplumunda örgütsel sessizliğin ne Japon kültüründe olduğu gibi (Fujio, 2004) olumlu havanın bozulmaması adına pozitif bir durum ne de Amerikan kültüründe olduğu gibi örgütün gelişmesi için düşüncelerini ifade etmekten kaçınma şeklinde olumsuz bir durum olarak algılandığını göstermektedir. Türk kültüründe örgütsel sessizlik Japon ve Amerikan kültürlerinin denge noktasında yer almaktadır. Kim ve Lee (2015), tarafından yapılan bir araştırmada sessizliğin, olumsuz bir davranış olarak görülmediği, aksine örgütsel bağlllık üzerinde olumlu bir etkiye sahip olduğu ortaya konulmuştur.

Öğretmenlerin kendi müdürlerinin toksik liderlik davranışlarına ilişkin algıları, onların örgütsel sessizlik algılarının çok küçük düzeyde de olsa yordayıcısı olarak görülmektedir. Katılımcıların kendi okul müdürlerinin toksik liderlik davranışlarına yönelik algıları, onların kendi örgütsel sessizlik davranışlarını bütün boyutlarda (okul ortamı, duygu, sessizliğin kaynağı, yönetici ve izolasyon) anlamlı olarak yordamaktadır. Örgütsel sessizliğin yordayıcısı olarak toksik liderlik davranışlarının yordama düzeyleri sessizliğin kaynağı boyutunda \%11 iken diğer dört boyutta bu etki \%10'un altında kalmaktadır. Ancak yordama gücü bazen olumlu bazen olumsuz olarak ortaya çıkmaktadır.

Toksik liderliğin kendi reklamını yapma boyutu örgütsel sessizliğin bütün boyutlarını (okul ortamı, duygu, sessizliğin kaynağı, yönetici, izolasyon) olumlu olarak yordamaktadır. Okul müdürlerinin, üst amirlerine karşı göstermelik tavırlar takınmaları; sadece kendilerine menfaat sağlayabilecek çalışanlara yardım teklifinde bulunmaları; başkalarının başarılarını kendilerine mal etme davranışları arttıkça öğretmenlerin sessiz kalma davranışları da buna paralel olarak artmaktadır.

Benzer şekilde, toksik liderliğin öngörülemezlik boyutu da örgütsel sessizliğin bütün boyutlarını olumlu olarak yordamaktadır. Okul müdürlerinin ruh hali; bilinmeyen nedenlerle çalışanlara öfkelenme; kendilerine ulaşılabilme düzeylerinin değişkenlik göstermesi davranışları yükseldikçe öğretmenlerin sessiz kalma davranışları da buna paralel olarak yükselmektedir.

Toksik liderliğin narsizm boyutu örgütsel sessizliğin bütün boyutlarını olumsuz olarak yordamaktadır. Müdürlerin, makam yetkisini kendi şahsına mal etme; kendilerini başkalarından daha yetenekli görme; kendilerini olağanüstü kişiler olarak görme davranışı artıkça öğretmenlerin sessizlik davranışı gösterme düzeyleri azalmaktadır. Diğer bir ifade ile müdürler narsist davranışlar gösterdiklerinde öğretmenlerin sesleri yükselmekte ve bu davranışlara karş1 tepkiler ortaya çıkmaktadır.

Diğer taraftan toksik liderliğin otoriter liderlik boyutu; sessizliğin kaynağı, yönetici ve izolasyon boyutlarını olumlu yordarken, okul ortamı ve duygu boyutlarını olumsuz yordamaktadır. Yani müdürlerin çalışanları sıkı şekilde kontrol etme; çalışanların farklı yöntemler kullanmalarına izin vermeme; bütün kararları kendisi alma davranışları artıkça sessizliğin kaynağı, yönetici ve izolasyon boyutlarında öğretmenlerin sessizlik davranışı da artmaktadır. Okul ortamı ve duygu boyutlarında ise zıt yönlü bir durum söz konusudur. 
Toksik liderliğin istismar edici denetmenlik boyutu örgütsel sessizliğin "sessizliğin kaynăğ" boyutunu olumlu yordarken diğer dört boyutunu olumsuz yönde yordamaktadır. Başka bir deyişle, müdürlerin çalışanları kendi görevleri dışındaki işlerden sorumlu tutma; onları küçümseme ve aşağılama davranışları arttıç̧a sessizliğin kaynağı boyutu hariç diğer dört boyutta öğretmenlerin örgütsel sessizlikleri azalmaktadır.

Literatürde toksik liderlerin örgütsel süreç ve çıtılar üzerinde olumsuz etkileri bulunduğuna yönelik bulgular mevcuttur. Bu kapsamda Bowling ve Michel (2011) tarafından yapılan çalışmada, toksik liderlerin, sergiledikleri davranışlarla çalışanların örgütsel güven ve bağgl1lklarını düşürdügü̈ sonucuna ulaşılmıştır. Schmidt'e (2014) göre toksik liderlik, çalışanların iş tatmini, örgütsel güven, örgütsel bağlılık ve grupla çalışma verimliliği üzerinde doğrudan olumsuz bir etkiye sahiptir. Benzer şekilde Padilla, Hogan ve Kaiser (2007), toksik liderlerin, örgüt çıktıları üzerinde olumsuz etkiler bıraktıklarını ifade etmektedir.

Toksik liderlik davranışları, bazı durumlarda çalışanların örgütsel sessizliğe bürünmelerine neden olurken, bazı durumlarda da çalışanların toksik liderlik davranışlarına tepki gösterilmesine ve "örgütsel ses"in yükselmesine neden olmaktadır. Özellikle yöneticilerin narsist olarak tanımlanabilecek davranışları, çalışanların bu yönde davranışlar sergilemelerine neden olmaktadır. Okul müdürlerinin statüden kaynaklanan yetkilerini kendi şahıslarından ayrı olarak algılama, kendilerini diğer insanlarla eşit kabullenme ve kendilerini diğer insanlardan daha üstün yetenekli görmekten kaçınma davranışlarını sergilemeleri durumunda okul ortamının ve çalışma koşullarının olumlu etkilenmesi beklenebilir.

Araştırmada ulaşılan sonuçlara dayalı olarak aşağıdaki öneriler geliştirilmiştir.

1. Okul müdürlerinin toksik liderlik davranışı sergileme nedenleri nitel çalışmalarla daha farklı boyutlarıyla araştırılabilir.

2. Öğgretmenlerin örgütsel sessizlik düzeylerinin azaltılmasına yönelik daha kapsamlı çalışmalar yapabilir.

3. Müdürlerin toksik liderlik davranışları ile öğretmenlerin örgütsel sessizlik düzeyleri arasındaki ilişki, başka değişkenler ile birlikte araştırılabilir. 


\section{Kaynakça}

Appelbaum S.H. \& Roy-Girard, D. (2007). Toxins in the workplace: Affect on organizations and employees. Corporate governance: The International Journal of Business in Society, 7(1), 1728

Arl1, D. (2013). İlkokul müdürlerinin örgütsel sessizlik ile ilgili görüşleri. Trakya Üniversitesi Eğitim Fakültesi Dergisi, 3(2), 69-84.

Bildik, B. (2009). Liderlik tarzları, örgütsel sessizlik ve örgütsel bă̆lılık ilişkisi. Yayımlanmamış Yüksek Lisans Tezi, Gebze Yüksek Teknoloji Enstitüsü, Gebze.

Bowling, NA. \& Michel, JS. (2011). Why do you treat me badly? The role of attributions regarding the cause of abuse in subordinates' responses to abusive supervision. Work \& Stress, 25(4), 309-320. doi:10.1080/02678373.2011.634281

Boydak Özan, M., Türkoğlu, A. Z. ve Şener, G. (2010). Okul yöneticilerinin sergiledikleri demokratik tutum ve davranışlarının öğretmenlerin motivasyonuna etkisi. Fırat Üniversitesi Sosyal Bilimler Dergisi, 20(1), 275-294.

Cemaloğlu, N. (2007). Okul yöneticilerinin liderlik stillerinin farklı değişkenler açısından incelenmesi. Türk Ĕ̈itim Bilimleri Dergisi, 5(1), 73-114.

Crockett, D. (2013). Teacher silence in South Carolina public schools. Doctoral dissertation, University of South Carolina, Columbia, USA.

Çelebi, N., Güner, H., ve Yıldız, V. (2015). Toksik liderlik ölçeğinin geliştirilmesi. Bartın Üniversitesi Eğitim Fakültesi Dergisi, 4(1), 249-268.

Çelik, V. (2012). Ĕgitimsel Liderlik. Ankara: Pegem A Yayıncılık.

Çoğaltay, N., Karadağ, E. ve Öztekin, Ö. (2014). Okul müdürlerinin dönüşümcü liderlik davranışlarının öğretmenlerin örgütsel bağlılı̆̆ına etkisi: Bir meta-analiz çalışması. Kuram ve Uygulamada Ĕ̈itim Yönetimi Dergisi, 20(4), 483-500.

Daşçı, E. (2014). İlköğretim kurumu yöneticilerinin liderlik tarzları ile öğretmenlerin yaşadıkları yıldırma (mobbing) ve örgütsel sessizlik davranışları arasındaki ilişki. Yayımlanmış Yüksek Lisans Tezi, Gazi Üniversitesi Eğitim Bilimleri Enstitüsü, Ankara.

Demirtaş, Z. (2018). The Relationships between organizational values, Job satisfaction, organizational silence and affective commitment. European Journal of Education Studies, 4(11), 108-125.

Demirtaş, Z., Özdemir, T. Y. ve Küçük, Ö. (2016). Okulların bürokratik yapısı, örgütsel sessizlik ve örgütsel sinizm arasındaki ilişki. Kuram ve Uygulamada Eğitim Yönetimi, 22(2), 193-216.

Demirtaş, Z. ve Nacar, D. (2018). Öğretmenlerin iş doyumu ve örgütsel sessizlik algıları arasındaki ilişki. Journal of Educational Reflections, 2(1). 13-23.

Dobbs, J.M. (2014). The Relationship between perceived toxic leadership styles, leader effectiveness, and organizational cynicism. Doctoral Dissertation, University of San Diego, San Diego, USA.

Dunn, M.W., Dastoor, B. \& Sims, R.L. (2012). Transformational leadership and organizational commitment: A cross-cultural perspective. Journal of Multidisciplinary Research, 4(1), 45-59.

Dyck, D. (2001). The toxic workplace. Benefits Canada, 25(3), 52-57.

Eğinli, A. T. ve Bitirim, S. (2008). Kurumsal başarının önündeki engel: Zehirli (toksik) iletişim. Selçuk Üniversitesi İletişim Fakültesi Akademik Dergisi, 5(3), 124-140.

Fujio, M. (2004). Silence during intercultural communication: a case study. Corporate communications: An International Journal, 9(4), 331-339. doi: 10.1108/13563280410564066

Goldman, A. (2006). High toxicity leadership: Borderline personality disorder and the dysfunctional organization. Journal of Managerial Psychology, 21(8), 733-746. doi: 10.1108/02683940610713262

Gül, H. ve Özcan, N. (2011). Mobbing ve örgütsel sessizlik arasındaki ilişkiler: Karaman il özel idaresinde görgül bir çalışma. Kahramanmaraş Sütçü Imam Üniversitesi İktisadi ve İdari Bilimler Fakültesi Dergisi, 1(2), 107-134. 
Henriksen, K. \& Dayton, E. (2006). Organizational silence and hidden threats to patient safety. Health Services Research, 41(4 Pt 2), 1539-1554.

Kahveci, G. ve Demirtaş, Z. (2013). Okul yöneticisi ve öğretmenlerin örgütsel sessizlik algıları. School administrator and teachers' perceptions of organizational silence. Eğitim ve Bilim / Education and Science, 38(167), 50-64.

Karaman, G. (2015). Okul müdürlerinin kullandıklarl güç kaynakları ile öğretmenlerin örgütsel sessizlik davranışları arasındaki ilişki. Yayımlanmamış Yüksek Lisans Tezi, Dumlupınar Üniversitesi Eğitim Bilimleri Enstitüsü, Kütahya.

Karasar, N. (2012). Bilimsel Araştırma Yöntemi. Ankara: Nobel Yayın Dağıtım.

Kahya, C. (2015). Örgütsel sessizlik ve tükenmişlik sendromu ilişkisi. Electronic Turkish Studies, 10(10), 523-546.

Kılıç, G., Tunç, T., Saraçlı, S. ve Kılıç, İ. (2013). Örgütsel stresin örgütsel sessizlik üzerine etkisi: Beş y1ldizlı termal. Turk Journal of Business Research, 5(1), 17-32.

Kılıç, R., Keklik, B. ve Yıldız, H. (2014). Dönüştürücü etkileşimci ve tam serbesti tanıyan liderlik tarzlarının örgütsel sessizlik üzerindeki etkisini belirlemeye yönelik bir araştırma. Journal of Management \& Economics, 21(2), 249-268.

Kılınç, E. (2012). Hekim ve hemşirelerde örgütsel vatandaşlık davranışı, örgütsel sessizlik, çalışan performansı ve aralarındaki iliş̧kinin incelenmesi. Yayımlanmamış Yüksek Lisans Tezi, Cumhuriyet Üniversitesi Sağllk Bilimleri Enstitüsü, Sivas.

Kırbaç, M. (2013). Eğitim örgütlerinde toksik liderlik. Yayımlanmamış Yüksek Lisans Tezi, İnönü Üniversitesi Eğitim Bilimleri Enstitüsü, Malatya.

Kim, P.Y. \& Lee, Y.L. (2015). Effects of abusive supervision on organizational silence and organizational commitment in travel agency. The Journal of the Korea Contents Association, 15(5), 507-514.doi: 10.5392/JKCA.2015.15.05.507

Lipman- Blumen, J. (2005). The allure of toxic leaders: Why followers rarely escape their clutches. Ivey Business Journal, 69(3), 1-40.

Lubit, R. (2004). The tyranny of toxic managers: Applying emotional intelligence to deal with difficult personalities. Ivey Business Journal, 68(4), 1-7.

Macklem, K. (2005). The toxic workplace. Maclean's, 118, 34-35.

McGowan, R.A. (2003). Organizational discourses: Sounds of silence. In 3rd International Critical Management Studies Conference Lancaster University, 1-7.

Milliken, F.J., Morrison, E.W., \& Hewlin, P.F. (2003). An exploratory study of employee silence: Issues that employees don't communicate upward and why. Journal of management studies, 40(6), 1453-1476. doi::10.1111/1467-6486.00387

Nartgün, Ş.S. ve Kartal, V. (2013). Öğretmenlerin örgütsel sinizm ve örgütsel sessizlik hakkındaki görüşleri . Bartın Üniversitesi Eğitim Fakültesi Dergisi, 2(2), 47-67.

Padilla, A., Hogan, R. \& Kaiser, RB. (2007). The toxic triangle: destructive leaders, susceptible followers, and conducive environments. The Leadership Quarterly, 18(3), 176-194.doi: 10.1016/j.leaqua.2007.03.001

Pinder, C.C., \& Harlos, K.P. (2001). Employee silence: quiescence and acquiescence as responses to perceived injustice. Research in Personnel and Human Resources Management, 20, 331-370. doi: 10.1016/S0742-7301(01)20007-3

Schmidt, A.A. (2008). Development and validation of the toxic leadership scale. Master of Science, University of Maryland, College Park, USA.

Schmidt, A.A. (2014). An examination of toxic leadership, job outcomes and the impact of military deployment. Doctor of Philosophy, University of Maryland, College Park, USA.

Şimşek, E. ve Aktaş, H. (2014). Örgütsel sessizlik ile kişilik ve yaşam doyumu etkileşimi: kamu sektöründe bir araştırma. Anadolu Üniversitesi Sosyal Bilimler Dergisi, 14(2), 121-136.

Şişman, M. (2002). Öğretim liderliği. Ankara, Pegem A Publishing. 
Şişman, M. (2012). Ĕgitimde mükemmellik arayışı ( etkili okullar). Ankara, Pegem A Yayıncılık.

Tahaoğlu, F. ve Gedikoğlu, T. (2009). İlköğretim okulu müdürlerinin liderlik rolleri. Kuram ve Uygulamada Eğitim Yönetimi, 58(58), 274-298.

Taşkıran, E. (2010). Liderlik tarzının örgütsel sessizlik üzerindeki etkisinde örgütsel adaletin rolü ve bir araştırma. Yayımlanmamış Doktora Tezi, Marmara Üniversitesi Sosyal Bilimler Enstitüsü, İstanbul.

Uğurlu, C.T. ve Üstüner, M. (2011). Öğretmenlerin örgütsel bağl1lık düzeylerine yöneticilerinin etik liderlik ve örgütsel adalet davranışlarının etkisi. Hacettepe Üniversitesi Eğitim Fakültesi Dergisi, 41(41), 434-448.

Uymaz, AO. (2014). Yıkıcı liderlik ölçeği geliştirme çalışması. Işsletme İktisadı Enstitüsü Yönetim Dergisi, 24(75), 37-57.

Yirci, R., Özdemir, T. Y., Kartal, S. E. ve Kocabaş, İ. (2014). Teachers' perceptions regarding school principals' coaching skills. School Leadership \& Management, 34(5), 454-469.

Whicker, M. L. (1996). Toxic Leaders: When Organizations Go Bad. Westport, CT: Quorum Books.

Wilson-Starks, K. Y. (2003). Toxic leadership, [Çevrim-içi: http://www.transleadership.com/ ToxicLeadership.pdf], Erişim tarihi: 16.12.2018. 


\section{Extended Abstract}

\section{Introduction}

School administrators, skillful and competent in ensuring and training organizational resources, are thought to be the most crucial factor required for attaining the goals of a school. A good school administrator is expected to be the leader of each employee within the school. Leadership is the power to affect others in attaining the objectives of the school. With this respect, an education service oriented towards enhancing the student with a personality and enabling the student to access functional information is offered by the school leader. The majority of studies on leadership have aimed at understanding "good" and "effective" leadership styles and explaining what the features of successful leadership are. Thus, leadership approaches such as instructional leadership, cultural leadership, ethical leadership, super leadership, visionary leadership and transformational leadership have attracted researchers and the positive influences of these leadership styles on organizations have been examined. However a common list on the general characteristics of leadership behaviors of school administrators has not been formed.

Very few studies in the literature have aimed at underlying the effects and results of dysfunctional, harmful leadership on organizations. Dysfunctional leadership has been dwelt upon in more detail in recent years. One of these leadership styles is toxic leadership. "Toxic leadership" is defined as assessing many negative characteristics together. Toxic, which is equivalent to "toxicus" in Latin, refers to a harmful item which consists of a toxin or poison and can harm the organism through these matters. The state of being under toxic due to these matters is called "toxicity".

Offering an environment where employees can freely express their opinions and thoughts about the organization is one of the prior behaviors expected by organization leaders. This is a duty expected by modern era organizations which aim at improving their quality standards as a response to increasing competition conditions and to respond to the expectations of the changing and improving society. With this respect, organizations expect their employees to increase information sharing, to consider their responsibilities, not to fear from expressing their ideas and to prioritize self-confidence. Although organizational silence constitutes a problem for many organizations, very few academic studies have been conducted on the relationship between organizational silence and leadership styles. This is due to the difficulty of dwelling on silence behavior. No studies examining the relationship between administrators' toxic leadership behaviors and organizational silence behaviors of the employees were found in the literature. It is crucial whether or not there is a relationship between toxic leadership behaviors of school administrators and teachers' silence behaviors in schools, which are educational organizations. It can be suggested that toxic behaviors of administrators have significant effects on organizational silence levels of teachers. With this respect, it is important to consider whether or not toxic leadership behaviors of school administrators predict the organizational silence behaviors of teachers.

\section{Method}

This study was carried out through the relational screening model, which aims at determining the presence or degree of change between two or more variables. The study population consists 
of 2422 secondary and 2603 high school teachers who work in the public secondary and high schools in Elazığ. The sample consists of eight secondary schools and ten high schools in the central district of Elazığ which were selected through the cluster sampling method. With this respect a total of 411, 215 secondary school and 196 high school, teachers participated in the study.

\section{Findings}

According to the results of the analysis conducted to determine the average scores of teacher perceptions concerning principal's toxic leadership behaviors and their own organizational silence behaviors, teacher perceptions concerning toxic leadership behaviors of their school principals are at I disagree level and their perception levels concerning their own organizational silence behaviors are at moderate level for all dimensions.

According to the regression analysis results concerning toxic leadership behaviors predicting the five dimensions of organizational silence, five dimensions of toxic leadership significantly predict organizational silences of teachers at the school atmosphere dimension $(\mathrm{F}=$ 7.026; $\mathrm{p}=.000)$; emotion dimension $(\mathrm{F}=5.269 ; \mathrm{p}=.000)$; resource of silence dimension $(\mathrm{F}=$ 9.899; $\mathrm{p}=.000)$; administrator dimension $(\mathrm{F}=5.043 ; \mathrm{p}=.000)$ with a low degree of effect and isolation dimension $(\mathrm{F}=7.540 ; \mathrm{p}=.000)$.

\section{Conclusion and Discussion}

According to the responses that teachers working in secondary and high schools gave to the organizational silence scale, teachers display organizational silence behaviors at a moderate level. In addition, teachers don't perceive their school principals as displaying toxic leadership behaviors.

Teacher perceptions concerning their principals' toxic leadership behaviors are observed to be -although at a low level- predictors of their organizational silence perceptions. Participant perceptions concerning toxic leadership behaviors of their school principals significantly predict their organizational silence behaviors at all dimensions (school atmosphere, emotion, resource of silence, administrator and isolation). As the predictors of organizational silence, the predictor levels of toxic leadership behaviors were at $11 \%$ for the resource of silence dimension and this effect was below $10 \%$ for the other four dimensions. However, the predictive power sometimes emerges as positively or negatively. 